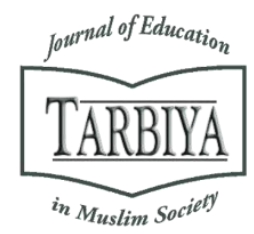

Available online at TARBIYA: Journal of Education in Muslim Society Website:

http://journal.uinjkt.ac.id/index.php/tarbiya

TARBIYA: Journal of Education in Muslim Society, 7(1), 2020, 67-77

\title{
THE IMPLEMENTATION OF LAPTOP MOBILE IN THE TEACHING-LEARNING PROCESS IN ISLAMIC BOARDING SCHOOL
}

\author{
Evi Fatimatur Rusydiyah*, Fiena Saadatul Ummah, Ali Mudlofir \\ UIN Sunan Ampel Surabaya, Indonesia \\ E-mail: evifatimatur@uinsby.ac.id
}

Received: $10^{\text {th }}$ December 2019; Revised: $14^{\text {th }}$ April 2020; Accepted: $30^{\text {th }}$ June 2020

\begin{abstract}
Computer literacy has become an interesting issue in the field of education as the integration of technology in education develops rapidly and continues to increase in the future. One aspect of computer literacy teacher's and student's perceptions and attitudes to use computers for classroom instruction. Unfortunately, this has been a challenge for incorporating technology during the teaching and learning process. The current study aims to analyze the implementation of the use of a mobile laptop in the class and unfold the student's attitudes toward using laptops during their learning activities. This research was a survey study that includes interviews, observation and documentation as a data collection technique. The subject of the study is 312 students from seventh to ninth grade. Data analysis was done by the following steps: data collection, data reductions, data analysis, and conclusion making. The study finds that 1) course content and learning activities have been predetermined/ predesigned and stored in the laptops, 2) every student have access to the device with the help of group work. The study also reveals that the attitude of students toward the use of laptops in the classroom process is positive in the sense that they show satisfaction on the use of laptops. They also acknowledge the advantages of the computer for their learning and show high awareness of the importance of keeping the devices maintained and secured.
\end{abstract}

Keywords: instructional technology; mobile laptop; instructional media; learning activities

\section{Abstrak}

Salah satu bidang Tehnologi pembelajara adalah pemanfaatan teknologi informasi sebagai media pembelajaran. Hal tersebut selaras dengan perkembangan abad 4,0. Kemampuan siswa dalam menggunakan dan memanfaatkan computer (Komputer Literasi) menjadi isu yang menarik saat ini. Komputer literasi menjadi bagian dari teknologi pembelajaran. Tujuan dari penelitian ini untuk menganalisis implementasi penggunaan laptop Mobile dalam aktivitas belajar di kelas dan bagaimana respon siswa dalam penggunaan laptop Mobile di kelas. Penelitian ini dilakukan dengan survey. Sedangkan metode pengumpulan datanya dilakukan dengan cara wawancara, observasi, dan dokumentasi. Subjek penelitian ini adalah siswa kelas VII, VIII, dan VIII sejumlah 312 anak. Analisis penelitian ini dilakukan dengan cara mengumpulkan data, mereduksi, menganalisis, dan membuat kesimpulan. Hasil penelitian ini menunjukkan bahwa implementasi penggunaan laptop mobile dilakukan saat proses belajar mengajar dilakukan dengan cara 1) semua materi dimasukkan dalam laptop mobile, 2) semua siswa mendapatkan hak akses untuk menggunakannya, dan 3) aktivitas belajar sudah didesain dalam laptop mobile. Sedangkan respon siswa dalam menggunakan mobile laptop menunjukkan 1) tingkat kepuasaan dalam menggunakan laptop mobile, 2) tingkat kemanfaatan dalam menggunakan laptop mobile, dan 3) tingkat tanggungjawab dalam merawat laptop mobile pada angka rerata yang paling tinggi pada lilihan stuju dan sangat setuju.

Kata kunci: Teknologi pembelajaran; laptop mobile; media pembelajaran; aktivitas belajar

How to Cite: Rusydiyah, E. F., Ummah, F. S., Mudlofir, A. (2020). The Implementation of Laptop Mobile in the Teaching-Learning Process in Islamic Boarding School. TARBIYA: Journal of Education in Muslim Society, 7 (1), 67-77. doi:10.15408/tjems.v7i1.13650.

Permalink/DOI: http://dx.doi.org/10.15408/tjems.v7i1. 13650

*Corresponding author

TARBIYA: Journal of Education in Muslim Society, P-ISSN: 2356-1416, e-ISSN: 2442-9848

This is an open access article under CC-BY-SA license (https://creativecommons.org/licenses/by-sa/4.0/) 


\section{Introduction}

Technology has inevitably influenced all aspects of daily life. More people become technology-dependent to perform everyday tasks such as reading, distance communicating, shopping and finding directions. The use of technology such as computers, tablets, projectors and other mobile devices is expecting to continue to develop and more accessible. Education avoidably will benefit from the integration of technology in the classroom, especially in this digital era. Incorporating technology during teaching and learning process is not a new concept. It derived from the idea that as a more young generation is engaged in technology, they will learn more effectively in a technology-based classroom. The technology will bring a new dimension of the teaching and learning process. Kuhnel et all (2018, p. 333) argues that our prolonged traditional way of teaching is monotonous and is no longer useful to accommodate students' different learning styles.

Technology is digital media for students in the class (Abdulhak \& Darmawan, 2015, p. 84). Media encompasses all physical means of communication such as books, printed materials, computers, audiovisuals, internet, films, videos, and others (Yaumi, 2018, p. 7). It is in line with Halili (2019, p. 68) who argues that by using technology, students can search millions of information on the internet, interact and collaborate and so forth. Meanwhile, learning refers to conscious effort to conduct and manage the learning process to achieve learning goals. Thus, learning includes the interaction process between teachers and learners to exchange information. During this process, the media can help students to gain learning goals (Abdulhak \& Darmawan, 2015).

Media for instructional purposes can have two functions; It is a learning aid, and as learning resources. The teacher should design projects for their students using media. They can understand the subject and pedagogical knowledge. Media can support the teachinglearning process effectively. (Han et al., 2019, p. 114). In and the other side, this media would serve students to have a positive impact on their academic progress, affective development, behaviour goals, and learning motivation (Siyam, 2019, p. 2035). However, Uno and Lamatenggo (2014, p. 136) precaution that the teachers should be selective in using the media. They should acknowledge and use media that support learning as well as are required to design the use of media based on the learning goals and student's needs.

Meanwhile, media presented as essential tools that allow students or teachers to access knowledge and resources, such as a website (Ortega-Sánchez \& Gómez-Trigueros, 2019, p. 8). The former, Teachers were as learning sources. Nowadays, media can be resources that can engage students in deeper learning and enhance the learning experience (Ghavifekr \& Rosdy, 2015). Thus, the media serves as additional learning sources besides printed references and the teachers themselves.

Some standard media used in the school is the computer and its generic devices such as projectors, visual sources, and internet connection. Networks offer advantages for students to access and store loads of information quickly. Also, besides the incorporation of computers into the classroom process know widely as Computer-Based Instruction (CBI). $\mathrm{CBI}$ involves Computer Assisted Instruction (CAI) and Computer Aided Learning (CAL) (Munir, 2015, p. 176). Nevertheless, the school should consider students' needs and school environments and cultures before attempting to use the computer in the class. Furthermore, Udim and Etim (2016, p. 167) add that 
computers should contribute to support and enhance the learning process.

As a part of technology, computers have many advantages for the learning process, teachers and students. The use of computer offers new learning concepts such as distance courses and blended learning, makes learning closer to real-life, creates interactive classroom communication. For teachers, computers offer assistance to design more interesting various activities. It is emphasizing on students centred, create a more effective evaluation, adopt and adapt more innovative and significant teaching methods such as discovery learning, task-based teaching and project-based teaching. Computers also give benefits to students in the way that it can increase students' motivation. It encourages collaborative skills, enhances skills necessary for the digital era, such as critical thinking and problem-solving.

Despite all the significant impacts on education, the implementation of computers in the classroom process faces many challenging. Standard challenging comes from teachers' perspective and students' attitude toward the integration of networks or other technological media in education. Some teachers are found defensive toward the use of technology as they view that technology can bring more harm than its' advantages on students' achievement. Furthermore, Soykan (2016) argues that although nearly almost all students open to the use of the computer, they often fail to make use of them for intended educational purposes.

Regarding the problem above, it is essential to conduct a study which analyzes teachers' and students' attitude toward the integration of computers in the classroom process. There many previous studies (Soykan, 2016) (Kelvin Udim \& Akon Etim, 2016) (Ghavifekr \& Rosdy, 2015) (Fauzan \& Pimada, 2018) (Kuhnel et al., 2018) (Rusydiyah et al., 2019) that conducted the same topics. However, this current study is different from them in the sense of the setting and context. The present research focuses on analyzing the implementation of a mobile laptop in Insan Cendekia Mandiri Boarding School, Sidoarjo, Indonesia. It also attempts to find students' attitudes toward them. Thus, this study expects to unfold the students' computer literacy competence.

\section{A brief of SMP Islam Insan Cendekia Mandiri Boarding School dan Its Laptop Mobile}

The setting, as well as the subject of the study, is Islam Insan Cendikia Mandiri boarding school which, is located in Sidoarjo, Indonesia. Under the affiliation of Yayasan Yatim Mandiri, it manages both junior and senior high school levels. The researcher chose This school because it has been integrating technology-based media in the classroom process, namely the mobile laptop, for two years.

Mobile laptops are available in every class of both school levels, although the number of them is limited. During the classroom process, students do group works and use the device in addition to course books or other written references. The use of mobile laptops initially is due to the lack of learning resources such as course books. To enrich references can trough the use of media, which students can use to help their learning experiences. Later, the usage of this media is to encourage students to access open resources that provide countless yet comprehensive information. Furthermore, by using this device, students can store the information on the computer and back to it whenever they need it for their presentation or other works.

There is maximizing the use of a mobile laptop. There should be any integration between learning resources such as course books and computers. For example, students read and gain the necessary information or knowledge from 
course books. Then they can do projects which require them to use tech for comprehensive understanding. The integration of technology will not only help students be more engaged, but they also can take control over their learning.

\section{Educational Technology: Computer-based Learning}

Educational technology is the integration of technology in education and the classroom process. This kind of communication media has experienced rapid development and brings many benefits for teaching and learning. Udim and Etim (Kelvin Udim \& Akon Etim, 2016) argue that in the context of education, technology refers to the process of applying tools for educational purposes. In other words, it is a combination of the learning process and tools to address educational needs and problems with the emphasis of using the latest technology, such as computers and other related technological devices.

Classroom process can use Technological media. It is also known as instructional media. It can encourage instructional communication between teachers and students and create a more effective learning process and the result (Adamy \& Boulmetis, 2006, p. 102). Instructional educative media can be either software or hardware (Nasution, 2012). The software includes designing and analyzing the learning activities and sequences based on learning goals as well as developing learning evaluation. Meanwhile, hardware involves radio, computer, television and other devices.

Furthermore, the media should have the following characteristics to serve as instructional educative media. First, it should include direct or indirect teaching aids that are effective to use in the classroom. Next, it should be used in and help with the instructional communication process. Then, it should have normative content for educational purposes, and it should serve to inspire the implementation of a variety of teaching methods during the teaching and learning process.

Also, besides the development of information and communication, technology has had enormous influences on education, especially in the classroom process. With the growing use of technology, the school has experienced shifts. It is such as the change from drilling to performance, from physical activities to network activities, from paper to online. It is too from learning face to face in the class to be more flexible learning regardless of the places, from cycle times to virtual time (Sutopo, 2013, p. 12).

Ghavifekr and Rosdy (Ghavifekr \& Rosdy, 2015) argue that students nowadays have been already familiar with and engaged with technology. Therefore, they will learn better in a technology-based classroom process. Effective integration of technology contributes to create active learning, make the classroom more dynamic, and leads to students-centred learning. Information and communication technology create young generations to be tech-savvy and are ready to join the workforce in the future, such as in business, industries, military and educational institutions.

The teacher can integrate technology inside classrooms. Teachers are required to have the skill to use technology and apply them for educational purposes. Involving technology in class is very useful. They are such as socialization, utilization, integration, reorientation, and revolution (Montrieux et al., 2015, p. 2). Socialization includes the stage where the teacher becomes aware of the technology and its potential use. At the same time, revolution refers to the stage where technology is a learning tool that is woven smoothly into the teaching and learning process. 
One kind of technology that is commonly in education is computers. The computer can be operated easily and can store a large amount of data. Due to its user-friendly, most people use the computer in the world, including teachers, students, workers and entrepreneurs (Sutopo, 2013). From inside the classroom, teachers and students use the computer to help with the teaching and learning process. For the teacher, computers provide access to the internet to design more engaging learning activities, serve capable teaching equipment, and create more independent learning. Meanwhile, for students, the use of computers helps them to do their assignment or projects, helps with a deep understanding, encourage student-centred learning, overcomes communication issues, encourages collaboration, and increase their learning motivation (Semerci, 2018, p. 150).

Also, besides the use of computers in the classroom does not only give advantages for individual development, but it can benefit students to build a network system. Computers enable the student to communicate with their peers or colleagues and teachers inside and beyond the classroom, which eventually allows for networks and communication ability (Uno \& Lamatenggo, 2014). The ability to communicate and interact will make the classroom activities more effective.

Despite all benefits computers can offer for pedagogical settings, they, however, are unlikely to replace the role of teachers in the class. Computers are just tools and machines intended to help the teachers' jobs. Teachers have parts that a computer or other media cannot do, such as building rapport with students, inspiring and being a role model for them. On top of that, how powerful computers can make changes in the instructional process is highly depended on who operates and control them. Therefore, teachers and students should be literate of technology for technology can bring a useful contribution to the learning process. Since the usage of instructional educative media gives tremendous advantages for education, computer literacy is an important requirement.

\section{Method}

The study used a qualitative approach. The researcher collects data through interviews, observation and documentation processes. The objective of this approach is to describe empirical data from a phenomenon in-depth, detail and entirely. Furthermore, the study is phenomenological. Researchers attempted to explain or uncover the meaning of the concept or event of experience based on the awareness that occurs in some individuals (Agustinova, 2015 , p. 28). In other words, phenomenological studies describe the general meaning of several individuals on their various life experiences related to concepts or phenomena. In this study use empirical transcendental phenomenology. It means that the researchers developed a textural description of the experiences of the participants, a structural description of their experience from the standpoint of conditions, situations, and contexts, and a combination of textural and structural specifications to convey the essence of the whole experience (Creswell, 2015, p. 110). They are collecting data is using Nonparticipatory observation, semi-structured interviews, and documentation. This research use observation to find out first-hand the learning process which uses Mobile Laptops as a media in teaching and learning activities. The observation was done directly, which the presence of the researchers or indirectly using assistive devices such as cameras and other recording devices without researchers' attendance.

Semi-structured interviews were chosen because it gives more flexibility for researchers to ask questions and use interview guidelines for 
further questions. In addition, the interviewees were expected to provide various information needed during the research process through interviews in the form of statements, information, or data that can help in understanding the problem. The informants for this study were 312 students of Insan Cendekia Middle School grade seventh to the tenth and the teachers. Students become respondent about the use of this mobile laptop to see their motivation in using the media. In the same time, teachers become respondent about the implementation of mobile learning.

Data analysis is in some following steps: 1) collecting all the data from observations, interviews and documentation in the form of field notes obtained from various informants, 2) selecting the appropriate data based on the aim, 3) grouping the data according to the discussion of the problem, 4) analyzing the data in each category, and 5) making a conclusion of Mobile Laptop usage in the learning process (Creswell, 2015).

\section{Results and Discussion}

The implementation of using mobile laptops during classroom process in Insan Cendekia Mandiri Boarding School, Sidoarjo

The study found that the use of mobile technology in this school opens a novel dimension of instructional communication. Both teachers and students learn how to use mobile technology for teaching and learning. They collaborate to make the most of mobile technology for learning experiences. This finding is in line with Vasilache (2016, p. 1428), who finds that the use of technology in education contributes to the enrichment of lessons for teachers and students (Vasilache, 2016). The finding also confirms Soykan's (Soykan, 2016) who finds that the use of computers and the internet which is a necessity for individuals who are in line with rapid technological developments has gained a new dimension with the introduction of mobile technology (Soykan, 2016).

The implementation of a mobile laptop during the learning process has three functions. First, it designs concepts and strategies for using media. Second, it creates student activities in class using the media. Third, it develops teachers' supervision of the use of technology during the classroom process (Semerci, 2018). Regarding the first function, the study found that the schools have invested time and source before implementing technology in the classroom to design concepts and strategies. In the beginning, the school invited and collaborated with the expert team to develop ideas and strategies that will use with the integration of mobile laptops. Teachers were also involved in decision making, especially in deciding for a teacher to choose materials or courses. Teacher's training then was conducted to empower teachers to use a mobile laptop with the intended materials. Informant 19 says that

When Shcool implements the media, the team has trained us on how to prepare and make it (contents). We were given step by step training on how to use this (contents) with mobile laptop

Informant 9 describes one of the strategies of integrating mobile laptops for classroom processes. He/She reported

students faces problems in learning material, which then students must find answers to these problems by using a mobile laptop as a means of digital literacy. After that, students make a PowerPoint (PPT) to present their opinions or answers.

The training was positive. It helps to raise teachers' awareness of the importance of technology in education as well as to motivate them to learn more, as reported by informant 19 
The use of mobile laptops makes us learn how we use technology in learning. I have to learn a lot to use it so the classroom activities will vary. The source of knowledge is not only me as a teacher and a book. But also a source that has been designed by the school

It is apparent from the quotes above that most interviewees have been aware that teachers need to have technology pedagogical content knowledge to incorporate technology in the classroom. Teacher competence does not only master the content, but they have also required technology and have educational skills (Rusyidah, 2019, p. 67). It is in line with the Regulation of Ministry Education and Culture, which suggests that teachers must have professional competence such as paedagogic, personal and social skills. Professional expertise also includes the ability of teachers to utilize technology as a learning medium (Republik Indonesia, 2007, p. 4).

Regarding the second function, the study found that the school has a policy that regulates the use of the mobile laptop in group works. The vice headmaster who in charge of curriculum reported that

There are only 60 devices divided into 12 classes. Thus, each room class has five laptops. However, when one-room class have outdoor activities, for example, library fieldwork or memorization al-Quran, other room classes can use the laptops

The quote shows that the policy conduct due to the limitation of the number of devices. However, instead of being a problem, the school treats it as a chance to encourage students to learn collaborative learning.

There is a third function. Supervision is done by involving students' roles. Teachers point to team leaders who are responsible for keeping the devices used and stored appropriately. Every class stores Laptops in a cupboard. IT staff will control and check it for maintenance every week under the supervision of the Vice-Principal who in charge of facilities and infrastructure.

Besides, the study found that in integrating the laptops in the teaching and learning process, the schools apply three approaches. They are integration, improvement and complement approaches. The Integration approach is the application of ICT in a field of study that involves concepts and skills to improve student achievement. In this regard, the schools integrate ICT with the course content. The laptops contain reading materials, handout and students' worksheets.

The enhancement approach is the use of ICT to create a variety of learning experiences and activities on the topics to be presented. For example, the use of Microsoft Powerpoint used to give issues in a creative way which allows for discussion and brainstorming. The school uses this approach by designing classroom activities that enhance students' independency, collaborative and critical thinking skills. Those activities are on discovery, inquiry, problembased learning, dan Project based-Learning. Mudlofir and Rusydiyah (2016, p. 6) argue that those learning methods are innovative, which can motivate students to learn at another level and improve teachers' professional competencies.

The complementary approach refers to the idea that technology is media intended to support the learning process. This context in line with the condition of the schools. The purpose of incorporating mobile laptops is in line with the status of the school. The basic idea of holding a mobile laptop is because of the lack of textbooks. The school attempts to use a mobile laptop to keep students learn and to provide information students can access in addition to books.

Student's activities include doing the tasks given by the teacher by using a laptop as a source 
of literacy besides other references. This was confirmed by the Principal saying that

The activities that students of junior high school do include reading and writing using mobile laptops, making a slide for presentation and presentation. Meanwhile, the teacher goes around the class to monitor student activities. The teacher also makes an agreement with the students on when and how is the assignment should be submitted.

Ghavifekr and Rosdy (Ghavifekr \& Rosdy, 2015) state that technology-based teaching and learning offers a variety of interesting ways of learning which include educational videos, stimulation, data storage and various references that will make the learning process more engaging and meaningful. Nevertheless, teachers are required to actively participate in the use of multimedia during the classroom process. They must be trained on how to use multimedia and integrate them for instructional purposes to enhance critical thinking and creativity among students (Kelvin Udim \& Akon Etim, 2016). They must also learn to facilitate and encourage students to be responsible. It was also learning and avoid using those media for inappropriate goals or activities that do not bring significance for their development (Rusydiyah et al., 2019).

\section{Students responses in the use of mobile laptops at Insan Cedekia Mandiri Boarding School, Sidoarjo}

There are four categories for student's attitudes. They are satisfaction in, the usefulness of, and responsibility in using a mobile laptop. This theory adopts from Theory of the Technology Acceptance Model (TAM) (Davis, 1989, p. 320; Rafique et al., 2020). Furthermore, Student responses in the use of mobile laptop media can be seen in the table 1 .
Table 1. Student Attitude to the use of mobile laptops during classroom process

\begin{tabular}{l|l|l|l|l|l}
\hline Statement & SD & D & N & A & SA \\
\hline $\begin{array}{l}\text { I found that using } \\
\text { mobile laptops is more } \\
\text { exciting than using } \\
\text { books }\end{array}$ & 9 & 11 & 40 & 101 & 151 \\
\hline $\begin{array}{l}\text { I found that I am more } \\
\text { motivated to learn with } \\
\text { mobile laptop than } \\
\text { with books }\end{array}$ & 7 & 9 & 42 & 112 & 142 \\
\hline $\begin{array}{l}\text { I can use the Mobile } \\
\text { laptop independently } \\
\text { without teacher's help }\end{array}$ & 37 & 30 & 82 & 89 & 73 \\
\hline $\begin{array}{l}\text { I can carry out } \\
\text { discussion with the help } \\
\text { of a mobile laptop }\end{array}$ & 22 & 30 & 70 & 92 & 98 \\
\hline $\begin{array}{l}\text { I can access many } \\
\text { information related to } \\
\text { topics I learned through } \\
\text { a mobile laptop }\end{array}$ & 10 & 19 & 40 & 140 & 103 \\
\hline $\begin{array}{l}\text { I am aware that using } \\
\text { mobile laptops allows } \\
\text { for collaboration skills }\end{array}$ & 11 & 15 & 51 & 123 & 112 \\
\hline $\begin{array}{l}\text { I have to protect my } \\
\text { group's mobile laptop } \\
\text { from any damages }\end{array}$ & 3 & 10 & 26 & 121 & 152 \\
\hline $\begin{array}{l}\text { Notes: } \\
\text { SD= Strongly Agree }\end{array}=$ Disagree \\
$\begin{array}{l}\text { N= Neutral } \\
\text { SA Agree Strongly Agree }\end{array}$
\end{tabular}

The table 1 shows that students' attitudes toward the use of mobile laptops relatively positive. This result is in line with Soykan's study (Soykan, 2016), which reports that education actors; students, teachers, and parents view the use of tablets or computers in education to bring many advantages. For example, visual media offer by computers or tablets can encourage a variety of and exciting interactions among students and with the teachers. As a result, it is likely increasing and elevate students' learning phases. Medias such as computers and tablets are also user-friendly as teachers and students can share the materials easily.

Besides, Trimmel and Bachman (2004, p. 152) also find a similar result in their study. It reports that most students are motivated in using Mobile Laptops which eventually influence students' enthusiasm in their learning. It can be seen in the way that they are actively involved in 
the problem-solving process during classroom discussions and make use of a computer to prepare for their presentations such as making slides using Microsoft PowerPoint (PPT). The use of computers or other technological devices encourages collaboration skills. Furthermore, the fact that students are enthusiastic about using Mobile Laptops to access references for their assignments besides visiting a library for books shows their positive attitude towards the use of laptops as well as their level of learning interest. Further, it shows that students even can learn how to use technology for advanced methods appropriately.

The result of this study also confirms the study by Spanos and Sofos (2013, p. 523) dan Vasilache (Vasilache, 2016). Spanos and Sofos find students can think critically, collaborate with members of their groups in the process of problem-solving, can communicate well and have high creativity. This research also shows that with the ability to access the internet, students like doing experiments with software and techniques for learning. Thus, they can make presentations creatively. Furthermore, students experienced new ways and activities for learning and were more organized. Meanwhile, Vasilache finds that integrating technology for the classroom process allows more variety of interactive interaction. The class was alive since students were engaged in the learning activities.

Besides, Li and Lee (2016, p. 152) found in their research that there was a significant positive relationship between computer literacy and online learning attitudes among students. Computer literacy has a higher correlation with online learning attitudes. However, no statistically significant differences were found in online learning attitudes by sex or by age group.

The result of this study and those mentioned earlier show that most researches put an agreement on the significance of integrating technology in education. However, It is also inevitable that there are factors that support and inhibit the implementation of technology-based classroom process.

The study found that the designing of course content by experts and teacher training on teaching using technology devices were supporting factors for applying technology integration in the teaching and learning process. To encourage required skills in the $21^{\text {st }}$ century make a course contents such as critical thinking, collaboration, creativity, communication. These skills are needed to empower students to adapt to rapid information in a proper manner (Rusyidah, 2019).

The study also found the weakness of incorporating computers in the class. Students are found less responsible in doing their tasks. Students are easily distracted to access content that irrelated to their learning.

\section{Conclusions}

The implementation of mobile laptop media encourages to create student-centred learning. The Mobile laptop contains course materials, handouts, and students' worksheets. One of the goals of using the mobile laptop is students can work their works and learning activities quickly by making use of computers. Student activities in the class include making a slide using a Microsoft PowerPoint and presenting their projects. Students also use the laptop to access information such as readings, necessary to do their assignments or tasks. Meanwhile, The role of the teachers covers monitoring the discussion of students during the learning process and maintaining the laptop to work well.

Students show a positive attitude towards the use of mobile laptops during the classroom process. It explains in the sense that students show satisfactory in using laptops and view that the use of laptops in classroom activities brings 
many advantages for their learning. They also strongly agree that laptops' maintenance is their responsibility. Despite their high interest and motivation in learning with technology, students, however, attempt to access content that is not related to their topics for materials as a result of easy access to the internet. This context calls for further discussion for the school itself and probably for other research to find the solution for this problem.

\section{References}

Abdulhak, I., \& Darmawan, D. (2015). Teknologi Pendidikan. PT. Remaja Rosdakarya.

Adamy, P., \& Boulmetis, J. (2006). The impact of modeling technology integration on preservice teachers' technology confidence. Journal of Computing in Higher Education, $17(2)$,

100-120.

https://doi.org/10.1007/BF03032700

Agustinova, D. E. (2015). Memahami Metode Penelitian Kualitatif Teori Dan Praktik. Calpulis.

Creswell, J. W. (2015). Penelitian Kualitatif Dan Desain Riset: Memilih Antara Lima Pendekatan. 3rd ed. Pustaka Pelajar.

Davis, F. D. (1989). Perceived usefulness, perceived ease of use, and user acceptance of information technology. MIS Quarterly: Management Information Systems, 13(3), 319-339. https://doi.org/10.2307/249008

Fauzan, U., \& Pimada, L. H. (2018). ICT-Based Teaching of English at Madrasah Aliyah In Kalimantan. TARBIYA: Journal of Education in Muslim Society, 5(2), 193211.

Ghavifekr, S., \& Rosdy, W. A. W. (2015). Teaching and Learning with Technology: Effectiveness of ICT Integration in Schools. International Journal of Research in Education and Science, 1(2), 175. https://doi.org/10.21890/ijres.23596
Halili, S. H. (2019). Technological Advancements in Education 4.0. The Online Journal of Distance Education and E-Learning, 7(1), 63-69. www.tojdel.net

Han, I., Han, S., \& Shin, W. S. (2019). Teachers' and students' perspectives on good teaching using technology in elementary classrooms. International Journal of Information and Communication Technology Education, 15(3), 103-116. https://doi.org/10.4018/IJICTE.201907010 8

Kelvin Udim, D., \& Akon Etim, E. (2016). Use of Multimedia in Teaching and Learning of Political Science in University of Uyo, Akwa Ibom State, Nigeria. Research in Pedagogy, 6(2), 154-170. https://doi.org/10.17810/2015.42

Kuhnel, M., Honal, A., Seiler, L., \& Ifenthaler, D. (2018). Mobile Learning Analytics in Higher Education: Usability Testing and Evaluation of an App Prototype. Interactive Technology and Smart Education 15(1).

Li, L.-Y., \& Lee, L.-Y. (2016). Computer Literacy and Online Learning Attitude toward GSOE Students in Distance Education Programs. Higher Education Studies, 6(3), 147. https://doi.org/10.5539/hes.v6n3p147

Montrieux, H., Vanderlinde, R., Schellens, T., \& De Marez, L. (2015). Teaching and learning with mobile technology: A qualitative explorative study about the introduction of tablet devices in secondary education. PLoS ONE, $10(12)$. https://doi.org/10.1371/journal.pone.01440 08

Mudlofir, A., \& Rusyidah, E. F. (2016). Desain Pembelajaran Inovatif. Raja Grafindo Persada.

Munir. (2015). Multimedia Konsep Dan Aplikasi Dalam Pendidikan. Alfabeta. 
Nasution, S. (2012). Teknologi Pendidikan. PT Bumi Aksara.

Ortega-Sánchez, D., \& Gómez-Trigueros, I. M. (2019). Massive open online courses in the initial training of social science teachers: Experiences, methodological conceptions, and technological use for sustainable development. Sustainability (Switzerland), 11(3). https://doi.org/10.3390/su11030578

Rafique, H., Shamim, A., \& Anwar, F. (2020). Investigating the Acceptance of Mobile Library Applications with an Extended Technology Acceptance Model (TAM). Computers and Education, 145, 103732. https://doi.org/10.1016/j.compedu.2019.10 3732

Republik Indonesia. (2007). Permendiknas No 16 Tahun 2007 tentang Standar Kualifikasi Akademik dan Kompetensi Guru.

Rusydiyah, E. F., Rakhmawati, R., Purwati, E., Hafiyusholeh, M., \& Asyhar, A. H. (2019). Multimedia Application Development With Islamic Critical Reflection Through 3-2-1 Technique for Novice Teacher Internship Program. Advances in Science, Technology and Engineering Systems Journa, 4(3), 100105. https://doi.org/10.25046/aj040314

Rusyidah, E. F. (2019). Teknologi Pembelajaran: Implementasi Pembelajaran Ea 4.0. Surabaya. UIN Sunan Ampel Surabaya Press.

Semerci, A. (2018). Students' views on the use of tablet computers in education. World Journal on Educational Technology: Current Issues, 10(2), 104-114. https://doi.org/10.18844/wjet.v10i2.3420
Siyam, N. (2019). Factors impacting special education teachers' acceptance and actual use of technology. Education and Information Technologies, 24(3), 20352057. https://doi.org/10.1007/s10639-01809859-y

Soykan, E. (2016). Views of students', teachers' and parents' on the tablet computer usage in education. Cypriot Journal of Educational Sciences, $\quad$ 10(3), 228-244. https://doi.org/10.18844/cjes.v1i1.68

Spanos, D., \& Sofos, A. (2013). The views and attitudes of students participating in a oneto-one laptop initiative in Greece. Education and Information Technologies, 20(3). https://doi.org/10.1007/s10639-013-9299-z

Sutopo, A. H. (2013). Teknologi Informasi Dan Komunikasi Dalam Pendidikan. Graha Ilmu.

Trimmel, M., \& Bachmann, J. (2004). Cognitive, social, motivational and health aspects of students in laptop classrooms. Journal of Computer Assisted Learning, 20(2), 151158. https://doi.org/10.1111/j.13652729.2004.00076.x

Uno, H. B., \& Lamatenggo, N. (2014). Teknologi Komunikasi Dan Informasi Pembelajaran. PT. Bumi Aksara.

Vasilache, S. (2016). Student Perspectives of Computer Literacy Education in an International Environment. Universal Journal of Educational Research, 4(6), 1426-1431. ttps://doi.org/10.13189/ujer.2016.040620

Yaumi, M. (2018). Media Dan Teknologi Pembelajaran. Kencana. 